\title{
N0 Stage Finding
}

National Cancer Institute

\section{Source}

National Cancer Institute. NO Stage Finding. NCI Thesaurus. Code C48705.

A regional lymph node TNM finding indicating that there is no evidence of regional lymph node metastasis. 